\title{
Encapsulation of Phaseolus lunatus Protein Hydrolysate with Angiotensin-Converting Enzyme Inhibitory Activity
}

\author{
Jorge Carlos Ruiz Ruiz, Maira Rubí Segura Campos, \\ David Abram Betancur Ancona, and Luis Antonio Chel Guerrero
}

Facultad de Ingeniería Química, Universidad Autónoma de Yucatán, Periférico Norte. Km. 33.5, Tablaje Catastral 13615, Col. Chuburná de Hidalgo Inn, CP 97203, Mérida, YUC, Mexico

Correspondence should be addressed to Luis Antonio Chel Guerrero; cguerrer@uady.mx

Received 28 June 2013; Accepted 25 August 2013

Academic Editors: K. R. Davis, I. W. Marison, and J. C. Merchuk

Copyright (c) 2013 Jorge Carlos Ruiz Ruiz et al. This is an open access article distributed under the Creative Commons Attribution License, which permits unrestricted use, distribution, and reproduction in any medium, provided the original work is properly cited.

\begin{abstract}
The objective of recent research has been to seek alternative therapeutic treatments; for this reason, the use of protein hydrolysates from diverse sources has been studied. A way to guarantee that these treatments reach the site of action is through protection with covers, such as microcapsules. Therefore, proteins from the legume Phaseolus lunatus were hydrolyzed and encapsulated with a blend of Delonix regia carboxymethylated gum/sodium alginate $(50: 50 \mathrm{w} / \mathrm{w})$. Hydrolysis release conditions in a simulated gastrointestinal system were obtained using $\mathrm{CaCl}_{2}$ concentrations as the main factor, indicating that lower $\mathrm{CaCl}_{2}$ concentrations lead to an increased hydrolysis release. Beads obtained with $1.0 \mathrm{mM}$ of $\mathrm{CaCl}_{2}$ exhibited a better hydrolysate release rate under intestinal simulated conditions and the proteins maintained an $\mathrm{IC}_{50}$ of $2.9 \mathrm{mg} / \mathrm{mL}$. Capsules obtained with the blend of Delonix regia carboxymethylated gum/sodium alginate would be used for the controlled delivery of hydrolysates with potential use as nutraceutical or therapeutic agents.
\end{abstract}

\section{Introduction}

Enzymatic hydrolysis of food proteins has produced various biologically active peptides with immunostimulating, opioid, antithrombotic, anticariogenic, and bactericidal or angiotensin-converting enzyme (ACE) inhibitory functions and has been the focus of recent research [1]. The renin angiotensin system plays an important role in blood pressure and in cardiac and vascular functions. Renin produces decapeptide angiotensin I from angiotensinogen. ACE catalyzes the formation of angiotensin II by cleaving the dipeptide from the $\mathrm{C}$-terminal of angiotensin I in the vascular wall [2]. ACE inhibitors have been prescribed for hypertensive patients worldwide, and many clinical application data have demonstrated that ACE inhibitors significantly reduce the morbidity and mortality of patients with myocardial infarction or heart failure [3]. Thus, ACE inhibitors may induce skin rashes, angioneurotic edema, diarrhea, cough, and dizziness [4]. Because hypertensive patients often need life-long medical treatment, interest has been focused on the isolation and identification of ACE-inhibitors which may be obtained from new and varied sources like foods [5].

Legumes are widely consumed in south-eastern Mexico as a major dietary protein source in both human and animal diets. Phaseolus lunatus L. is distributed throughout Latin America, the southern United States, Canada, and many other regions worldwide. It is a reasonably drought-tolerant legume with reported yields as high as $1500 \mathrm{~kg} / \mathrm{ha}$ and is known to be an efficient organic fertilizer. The bean of P. lunatus is high in protein (24\%) that increases up to $70 \%$ when subjected to alkaline extraction to obtain protein concentrates [6]. Extensive hydrolysis of $P$. lunatus protein concentrates with commercial and digestive enzymes could therefore produce a number of peptides with a myriad of potential applications, for example, as a natural-source of therapeutic elements in medical treatments and/or as an ingredient in functional foods.

However, bioactive peptides orally administered to reduce blood pressure are liable to be digested and lose their activities. One of the main advantages of microsphere 
formulation is to provide stability for labile compounds that are rapidly degraded or cleared out in vivo. Cells or enzymes such as proteases in the surrounding tissues would not have contact with the protein until it is released from the microsphere matrix [7]. Microspheres could be readily injected subcutaneously or into other target sites or even given orally. In fact, developments in controlled release microsphere formulations have accelerated given the developments in polymer science and synthesis technology. The polymer must not alter the pharmacological properties of the drug and should not produce adverse side effects or any degradation product which has any other activity. It should be biocompatible, nontoxic, and nonirritant [8].

There are several natural polymers available, like starch, alginate, zein, chitin, or collagen. The use of modified polysaccharides with ionic charges to encapsulate substances with biological activity has become increasingly popular in the nutraceutical food and pharmaceutical industries. Microencapsulation protects nutraceuticals, keeps them stable in storage at room temperature, and ensures the release of an appropriate dosage at a gastric or intestinal $\mathrm{pH}$ [9]. Delonix regia trees are considered an ornamental species, and gum from its seeds has not been previously used to encapsulate nutraceutical substances in food and drugs [10]. Nonetheless, $D$. regia seed gum is potentially useful for microencapsulation because it contains galactomannan-type polysaccharides that are similar to those of guar gum (Cyamopsis tetragonolobus) and locust bean (Prosopis chilensis) gum [11]. Previous studies have demonstrated its capacity to form microcapsules as models of bioactive release molecules [12]. The few branched regions present in this flamboyant seed native gum consist of $\alpha$-D-mannose $(1 \rightarrow 4)$ linkages and $\alpha$-D-galactose $(1 \rightarrow 6)$ branches (mannose-galactose 2:1 ratio). Its mannose and galactose proportions are similar to those of guar gum but differ in terms of the $\mathrm{OH}$ bond position in the main chain; flamboyant gum has $\alpha$-D-mannose while guar gum has $\beta$-Dmannose [13].

In the present research, to retain the ACE inhibitory activity of peptides in the gastrointestinal tract, hydrolysates of $P$. lunatus beans were encapsulated in beads of carboxymethylated $D$. regia seed gum. Subsequently, the beads in vitro release capacity and ACE inhibitory activity of hydrolysate was evaluated.

\section{Materials and Methods}

2.1. Seeds and Chemicals. Delonix regia seed pods were collected in Yucatan, Mexico. The collection of dry seed pods was performed approximately 100 days after the flowering period, and physically undamaged seeds no longer than $1 \mathrm{~cm}$ in length were removed from the sample. A total of $5 \mathrm{~kg}$ of seeds was collected and stored in polyethylene bags at $4^{\circ} \mathrm{C}$ until use. Phaseolus lunatus seeds were obtained from the February 2012 harvest in the state of Yucatan, Mexico. All chemicals were reagent grade from JT Baker (Phillipsburg, $\mathrm{NJ}$ ), and pepsin was purchased from Sigma (Sigma Co., St Louis, MO, USA).
2.2. D. regia Seed Gum Extraction. Flour was produced from seed endosperm following Morochi et al. [10]. Seeds were hydrated in distilled water $(1: 5 \mathrm{w} / \mathrm{v})$ at $70^{\circ} \mathrm{C}$ for $10 \mathrm{~h}$. They were then wet milled (Tecator Cemotec 1090 Sample Mill, Höganäs, Sweden) to crack the seeds and free the endosperm and washed three times with distilled water to eliminate the husk and germ. The endosperm was dried at $55^{\circ} \mathrm{C}$ for $24 \mathrm{~h}$ in a circulating air oven (Imperial V Lab-Line Model $3476 \mathrm{M}$, Boston, USA) and milled (Thomas-Wiley Laboratory Mill Model 4, Swedesboro, NJ, USA), before being passed through a 20 mesh $(833 \mu \mathrm{m})$. D. regia gum extraction was done following Azero and Andrade [14], with some modifications. Briefly, the endosperm flour was suspended in water $(1: 30 \mathrm{w} / \mathrm{v}, \mathrm{pH} 7)$ and heated to $50^{\circ} \mathrm{C}$ under constant agitation for $30 \mathrm{~min}$. It was then filtered sequentially through $42(351 \mu \mathrm{m})$ and 100 mesh $(147 \mu \mathrm{m})$ to separate the fibrous particles from the gum. The filtered sample was precipitated in $70 \%(\mathrm{w} / \mathrm{v})$ ethanol, dried at $55^{\circ} \mathrm{C}$ for $24 \mathrm{~h}$ in a circulating air oven (Imperial V Lab-Line Model $3476 \mathrm{M}$, Boston, USA), and milled (Thomas-Wiley Laboratory Mill Model 4, Swedesboro, NJ, USA) to an 80 mesh $(173 \mu \mathrm{m})$ size.

2.3. Carboxymethylation. The D. regia gum was modified by carboxymethylation using sodium chloroacetate (SCA) under heterogeneous conditions following Bahamdan and Daly [15], with some modifications. A $70 \mathrm{~g}$ sample of gum was allowed to swell in $400 \mathrm{~mL}$ of 2-propanol with nitrogen, under constant agitation (Caframo RZ-1, Heidolph, Schwabach, Germany). After initial swelling, $24.8 \mathrm{~g}$ of $\mathrm{NaOH}$ solution (40\%) was added over a period of $20 \mathrm{~min}$, and the mixture was left to stand for $30 \mathrm{~min}$ at room temperature to allow further swelling. Sixty grams of SCA solution (40\%) was added over $30 \mathrm{~min}$, and the mixture was allowed to react for $1 \mathrm{~h}$. The reaction temperature was then raised to $70^{\circ} \mathrm{C}$ over $1 \mathrm{~h}$, and the reaction was allowed to proceed for $3 \mathrm{~h}$ at $70^{\circ} \mathrm{C}$. The mixture was cooled to room temperature and filtered. The resulting solid was washed and soaked in $80 \%(\mathrm{v} / \mathrm{v})$ methanol/water for $30 \mathrm{~min}$ to remove inorganic salts. The carboxymethylated gum was recovered by filtration, washed with 99.9\% methanol (Fermont 06121, Monterrey, Mexico), and dried overnight at $60^{\circ} \mathrm{C}$ in an oven (Imperial V Lab-Line Model 3476 M, Boston, USA).

2.4. Protein Concentrate. Selected grains were processed in a disk mill (model 4-E Quaker, Mill Straub Co., Philadelphia, PA, USA) until flour was produced. The flour was then sifted through 4.76 and $2.38 \mathrm{~mm}$ screens, and the hulls were removed with a fluidizing air bed. Samples were then milled in a Mykros impact mill until passing through a 20 mesh screen $(0.85 \mathrm{~mm})$ followed by milling in a Cyclotec 1093 (Tecator, Sweden) mill before being passed through a 60 mesh screen $(0.24 \mathrm{~mm})$. A single extraction was performed with $5 \mathrm{~kg}$ of flour. The flour was processed using the wet fractionation method of Betancur-Ancona et al. [6]. Briefly, whole flour was suspended in distilled water at a 1:6(w/v) ratio, $\mathrm{pH}$ was adjusted to 11 with $1 \mathrm{M} \mathrm{NaOH}$, and the dispersion was stirred for $1 \mathrm{~h}$ at $400 \mathrm{rpm}$ with a mechanical agitator (Caframo Rz-1, Heidolph Schwabach, Germany). This suspension was 
TABLE 1: $2^{2}$ factorial design used for Phaseolus lunatus hydrolysate encapsulation with flamboyant carboxymethylated gum/alginate and protein encapsulation efficiency.

\begin{tabular}{lccc}
\hline Treatment & $\mathrm{CaCl}_{2}(\mathrm{mM})$ & $\mathrm{pH}$ & Encapsulation efficiency (\%) \\
\hline 1 & 1.0 & 4 & $71.7^{\mathrm{c}}$ \\
2 & 3.0 & 4 & $67.3^{\mathrm{b}}$ \\
3 & 1.0 & 10 & $78.4^{\mathrm{d}}$ \\
4 & 3.0 & 10 & $71.8^{\mathrm{c}}$ \\
5 & 2.0 & 7 & $53.1^{\mathrm{a}}$ \\
6 & 2.0 & 7 & $53.3^{\mathrm{a}}$ \\
7 & 2.0 & 7 & $51.8^{\mathrm{a}}$ \\
8 & 2.0 & 7 & $52.0^{\mathrm{a}}$ \\
\hline
\end{tabular}

Different superscript letters indicate statistical difference $(P<0.05)$.

wet milled with a Kitchen-Aid food processor, and the fiber solids were separated from the starch and protein mix by straining through 80 - and 150-mesh sieves, followed by washing of the residue five times with distilled water. The proteinstarch suspension was allowed to sediment for $30 \mathrm{~min}$ at room temperature to recover the starch and protein fractions. The $\mathrm{pH}$ of the separated solubilized proteins was adjusted to the isoelectric point (4.5) with $1 \mathrm{~N} \mathrm{HCl}$. The suspension was then centrifuged at $1317 \times \mathrm{g}$ for $12 \mathrm{~min}$ (Mistral 3000i, Curtin Matheson Sci.), the supernatants were discarded, and the precipitates were freeze-dried at $-47^{\circ} \mathrm{C}$ and $13 \times 10^{-3}$ mbar. Until use, the protein isolate was stored in plastic containers at room temperature.

2.5. Enzymatic Hydrolysis. Protein concentrate hydrolysis was carried out using pepsin for $10 \mathrm{~min}$, substrate concentration $4 \%$, enzyme/substrate ratio $1: 10, \mathrm{pH} 2$ and temperature $37^{\circ} \mathrm{C}$ [16]. The reaction was stopped by heating to $80^{\circ} \mathrm{C}$ for $20 \mathrm{~min}$, followed by centrifuging at $1317 \times \mathrm{g}$ for $12 \mathrm{~min}$ (Mistral $3000 \mathrm{i}$, Curtin Matheson Sci.) to remove the insoluble portion. The degree of hydrolysis (DH) was calculated by determining free amino groups with o-phthaldialdehyde [17]: $\mathrm{DH}=$ $\left(\mathrm{H} / \mathrm{H}_{\text {tot }}\right) 100$, where $\mathrm{H}_{\text {tot }}$ is the total number of peptide bonds per protein equivalent, and $\mathrm{h}$ is the number of hydrolyzed bonds.

2.6. Hydrolysate Encapsulation. Carboxymethylated gum/ sodium alginate beads in a ratio $50: 50(\mathrm{w} / \mathrm{w})$ were produced based on Betancur-Ancona et al. [12]. A $2^{2}$ factorial design with 4 central points was used (Table 1). The tested factors and levels were $\mathrm{CaCl}_{2}$ concentration $(1$ and $3 \mathrm{mM})$ and $\mathrm{pH}$ (4 and 10). Response variable was the amount of protein encapsulated. $150 \mathrm{mg}$ of each gum and $400 \mathrm{mg}$ of hydrolysate were dispersed in $25 \mathrm{~mL}$ of deionized water. The dispersion was dropped into a $\mathrm{CaCl}_{2}$ solution with a peristaltic pump at a flow of $0.17 \mathrm{~mL} / \mathrm{s}$. The beads were left to harden for $30 \mathrm{~min}$.

2.7. In Vitro Release Studies. Each treatment's bead in vitro release capacity was evaluated with an adapted version of the method of Takagi et al. [18]. Briefly, $100 \mathrm{mg}$ of dry beads was added to $50 \mathrm{~mL}$ beakers containing $25 \mathrm{~mL} \mathrm{HCl}$ solution at $\mathrm{pH} 1.2$ with $0.2 \mathrm{M} \mathrm{NaCl}$ at $37^{\circ} \mathrm{C}$, to simulate gastric $\mathrm{pH}$. This mixture was stirred with a magnetic stirrer at $350 \mathrm{rpm}$ for $2 \mathrm{~h}$ on a plate shaker (Variomag Multipoint Electronic Rührer
HP, Daytona Beach, Florida). The beads were recovered by decanting the solution and then placed in $50 \mathrm{~mL}$ beakers containing $25 \mathrm{~mL} 0.25 \mathrm{M}$ phosphate buffer at $\mathrm{pH} 6.8$ and $37^{\circ} \mathrm{C}$, to simulate intestinal $\mathrm{pH}$. This mixture was stirred with a magnetic stirrer at $1.5 \mathrm{~g}$ for $3 \mathrm{~h}$. Protein content and residual ACE activity were calculated using $1.5 \mathrm{~mL}$ triplicate aliquots taken after processing with each $\mathrm{pH}$ system (i.e., gastric and intestinal).

2.8. ACE Inhibitory Activity. Angiotensin I-converting enzyme inhibitory activity was analyzed following Hayakari et al. [19]. Hippuryl-L-histidyl-L-leucine (HHL) is hydrolyzed by ACE to yield hippuric acid and histidyl-leucine. This method relies on the colorimetric reaction of hippuric acid with 2,4,6-trichloro-s-triazine (TT) in a $0.5 \mathrm{~mL}$ incubation mixture containing $40 \mu \mathrm{mol}$ potassium phosphate buffer $(\mathrm{pH}$ 8.3), $300 \mu \mathrm{mol}$ sodium chloride, $40 \mu \mathrm{mol} 3 \%$ HHL in potassium phosphate buffer ( $\mathrm{pH} 8.3$ ), and $100 \mathrm{mU} / \mathrm{ml} \mathrm{ACE}$. The mixture was incubated at $37^{\circ} \mathrm{C}$ for $45 \mathrm{~min}$ and the reaction terminated by adding TT $(3 \% \mathrm{v} / \mathrm{v})$ in dioxane and $3 \mathrm{~mL}$ of $0.2 \mathrm{M}$ potassium phosphate buffer ( $\mathrm{pH}$ 8.3). After centrifuging the reaction mixture at $10,000 \times \mathrm{g}$ for $10 \mathrm{~min}$, enzymatic activity was determined in the supernatant by measuring absorbance at $382 \mathrm{~nm}$. All runs were done in triplicate. ACE inhibitory activity was quantified by a regression analysis of ACE inhibitory activity (\%) versus peptide concentration and defined as an $\mathrm{IC}_{50}$ value, that is, the peptide concentration ( $\mu \mathrm{g}$ protein $/ \mathrm{mL}$ ) required to produce $50 \%$ ACE inhibition under the described conditions.

2.9. Statistical Analysis. All results were analyzed using descriptive statistics with central tendency and dispersion measures. One-way ANOVAs were run to evaluate content of protein encapsulate and ACE inhibitory activity during in vitro release studies. An LSD multiple range test was used to determine differences between treatments. All analyses were done according to Montgomery [20] and processed with the Statgraphics Plus version 5.1 software.

\section{Results and Discussion}

3.1. Delonix regia Seed Gum Extraction and Carboxymethylation. D. regia gum extraction produced $400 \mathrm{~g}$ of gum per $1 \mathrm{~kg}$ of endosperm flour. The carboxymethylation of the gum 


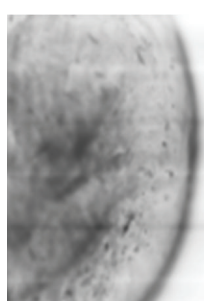

T1

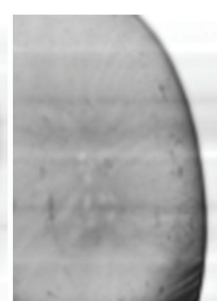

T2

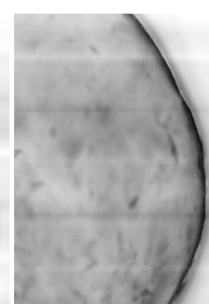

T3

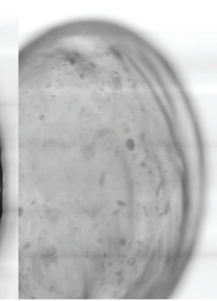

T4

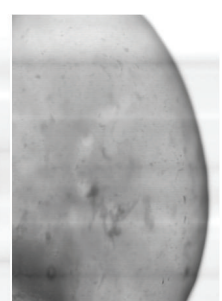

T5-T8

Figure 1: Morphology of flamboyant carboxymethylated gum/sodium alginate newly formed beads. T1 $\left(\mathrm{CaCl}_{2} 1.0 \mathrm{mM}, \mathrm{pH} 4\right)$, T2 $\left(\mathrm{CaCl}_{2}\right.$ $3.0 \mathrm{mM}, \mathrm{pH}$ 4), T3 ( $\left.\mathrm{CaCl}_{2} 1.0 \mathrm{mM}, \mathrm{pH} 10\right), \mathrm{T} 4\left(\mathrm{CaCl}_{2} 3.0 \mathrm{mM}, \mathrm{pH} 10\right)$, T5-T8 $\left(\mathrm{CaCl}_{2} 2.0 \mathrm{mM}, \mathrm{pH}\right.$ ).

resulted in a degree of substitution (DS) of 0.43 , equivalent to $14 \%$ carboxymethyl substitution. This DS was similar than those reported for gums with a similar mannose-galactose ratios $(2: 1)$ in their structure, as well as guar gum (Cyamopsis tetragonolobus) with 0.41 [19] and 0.42 for locust bean (Prosopis chilensis) [11].

3.2. Enzymatic Hydrolysis. Hydrolysis was monitored by measuring the extent of proteolytic degradation through the degree of hydrolysis (DH) according to the $\mathrm{o}^{-}$ phthaldialdehyde reaction with free amino groups. The $\mathrm{DH}$ produced at $10 \mathrm{~min}$ with pepsin was $12.4 \%$. Extensive protein hydrolysates, that is, those with a high degree of hydrolysis $(>10 \%)$, are used as protein supplements or as ingredients in special medical diets [21]. Recent research has focused on the properties of food protein-derived peptides, their biological activities, and potential health benefits. Peptides extracted from partial enzymatic hydrolysates of food proteins can provide specific health benefits, for example ACE inhibitors [22]. Peptides with biological activities have generally been isolated from food proteins via hydrolysis with digestive enzymes such as pepsin, pancreatin, trypsin, or chymotrypsin [22].

3.3. Hydrolysate Encapsulation. The reported concentrations of polymers used for gel formation vary from $1.5 \%$ to $2.5 \%$ with 0.05 to $1.5 \mathrm{M} \mathrm{CaCl}_{2}$ [23]. According to Chourasia and Jain [24], the use of polymer-blends increases the efficiency of protein delivery systems. In this study, a concentration of $3 \%$ of $D$. regia carboxymethylated gum/sodium alginate blend $(50: 50 \mathrm{w} / \mathrm{w})$ was tested for all treatments because preliminary tests had shown that blending in this ratio improves capsule formation. The bead morphology shows that newly formed beads had a spherical shape with similar sizes (Figure 1).

The protein content in beads ranged from 212.7 to $313.4 \mathrm{mg} / \mathrm{mL}$ (Figure 2). The higher content of protein was observed in treatment 3 and the lower content in central points. According to Figure 2, the content of protein (hydrolysate) in beads was determined by the amount of $\mathrm{CaCl}_{2}$ and $\mathrm{pH}$ with lower contents in treatments $5,6,7$, and $8\left(\mathrm{CaCl}_{2} 2.0 \mathrm{mM}, \mathrm{pH} 7\right)$ and higher in treatment 3 $\left(\mathrm{CaCl}_{2} 1.0 \mathrm{mM}, \mathrm{pH} 10\right)$. According to Chandramouli et al. [25], increasing $\mathrm{CaCl}_{2}$ concentrations induce a more densely cross-linked gel structure and increase the content of protein encapsulated. Findings in this study were somewhat

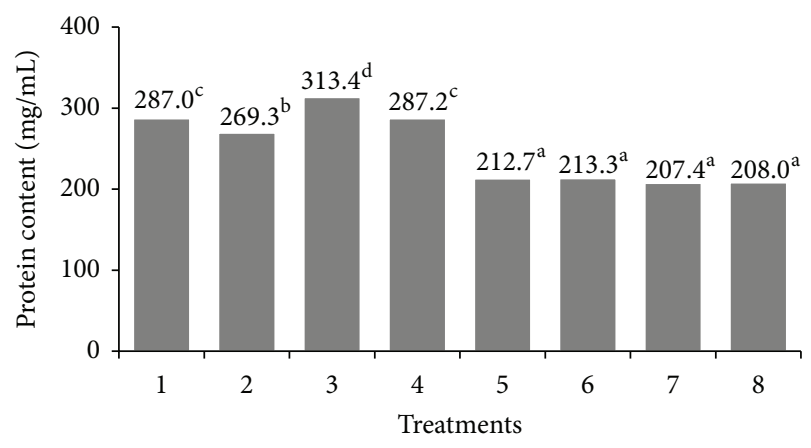

FIGURE 2: Influence of $\mathrm{CaCl}_{2}$ concentration and $\mathrm{pH}$ on the protein content in the flamboyant carboxymethylated gum/alginate beads. Different superscript letters indicate statistical difference $(P<0.05)$.

contradictory; at low concentrations of $\mathrm{CaCl}_{2}(1.0 \mathrm{mM})$, the content of protein was higher. The content of protein also was influenced by $\mathrm{pH}$. At high values of $\mathrm{pH}(\mathrm{pH}>8)$, the solubility of protein was found to increase and probably showed a better interaction with the polymer blend [26]. The efficiency of protein encapsulation in beads obtained at $\mathrm{pH} 10$ with $1.0 \mathrm{mM}$ of $\mathrm{CaCl}_{2}$ was over $78 \%$, while that in beads obtained at $\mathrm{pH} 7$ with $2.0 \mathrm{mM}$ of $\mathrm{CaCl}_{2}$ was over $53 \%$ (shown in Table 1).

3.4. In Vitro Release Studies. During the in vitro simulation of gastric conditions, the release of protein (hydrolysate) was detected for all bead formulations (Table 2). At $\mathrm{pH}$ 1.2, protein releases ranged from $10.5 \%$ to $73.1 \%$. Treatment $2\left(\mathrm{CaCl}_{2}\right.$ $3.0 \mathrm{mM}, \mathrm{pH} 4$ ) released only $10.5 \%$ of the protein in $2 \mathrm{~h}$, indicating the stability of beads. On the contrary, treatment $3\left(\mathrm{CaCl}_{2} 1.0 \mathrm{mM}, \mathrm{pH} 10\right)$ released $73 \%$ of the protein during the same time. Treatments obtained with $\mathrm{CaCl}_{2} 3.0 \mathrm{mM}$ were more stable under simulated gastric conditions than those obtained with $\mathrm{CaCl}_{2} 1.0$ and $2.0 \mathrm{mM}$. Using in vitro intestinal conditions, beads obtained with $\mathrm{CaCl}_{2} 1.0 \mathrm{mM}$ at $\mathrm{pH} 4$ released a higher content of protein (Table 2), which suggested that lower $\mathrm{CaCl}_{2}$ concentrations were needed to further enhance the extended release properties. This behavior is desirable because release in the intestinal environment (60.1\%), which is where absorption takes place bioactive components, occurs with the lowest concentration of calcium, with appropriate release value in the gastric environment (16.4\%). 
TABLE 2: Protein released and $\mathrm{IC}_{50}$ values at gastric and intestinal simulation conditions.

\begin{tabular}{lcccc}
\hline Treatment & \multicolumn{2}{c}{ Protein released (\%) } & & $\mathrm{IC}_{50}(\mathrm{mg} / \mathrm{mL})$ \\
& $\mathrm{pH} 1.2,37^{\circ} \mathrm{C}$ & $\begin{array}{c}\text { Intestinal } \\
\mathrm{pH} 6.8,37^{\circ} \mathrm{C}\end{array}$ & $\mathrm{GpH}$ & $\mathrm{IpH}$ \\
\hline 1 & $16.4^{\mathrm{c}}$ & $60.1^{\mathrm{c}}$ & $3.8^{\mathrm{a}}$ & $2.9^{\mathrm{c}}$ \\
2 & $10.5^{\mathrm{a}}$ & $39.4^{\mathrm{b}}$ & $4.1^{\mathrm{b}}$ & $3.3^{\mathrm{b}}$ \\
3 & $73.1^{\mathrm{d}}$ & $20.2^{\mathrm{a}}$ & $3.1^{\mathrm{c}}$ & $3.8^{\mathrm{a}}$ \\
4 & $14.2^{\mathrm{b}}$ & $40.3^{\mathrm{b}}$ & $3.9^{\mathrm{a}}$ & $3.8^{\mathrm{a}}$ \\
$\mathrm{CP}$ & $17.9^{\mathrm{c}}$ & $40.7^{\mathrm{b}}$ & $3.8^{\mathrm{a}}$ & $3.7^{\mathrm{a}}$ \\
\hline
\end{tabular}

Different superscript letters in the same column indicate statistical difference $(P<0.05)$.

3.5. ACE Inhibitory Activity. The protein concentration required to produce $50 \%$ inhibition of $\mathrm{ACE}\left(\mathrm{IC}_{50}\right)$ was used as an activity indicator. This indicator is expressed as $\mathrm{mg}$ protein $/ \mathrm{mL}$, with smaller values indicating a greater ACE-inhibiting power. The nonhydrolyzed Phaseolus lunatus protein concentrate showed no inhibitory activity on ACE. ACE inhibitory activity was generated from the Phaseolus lunatus protein after enzymatic hydrolysis. Hydrolysis is necessary in order to release ACE peptides from an inactive form within the Phaseolus lunatus protein. On the other hand, $P$. lunatus hydrolysate has good solubility in water, allowing incorporation into food matrices to generate physiologically functional foods for preventing hypertension as well as for therapeutic purposes. Treatment 3 released the highest content of hydrolysate during the gastric simulation with consequently higher ACE inhibitory activity (Table 2). Protein- and peptide-based therapeutic agents have unique physiochemical properties, such as high molecular weight, short half-life, and the requirement of a sustained plasma level for the desired therapeutic effect, which is liable to physical and chemical instability by gastric enzymes and harsh acidic environment, as well as first pass metabolism. In order to maintain the ACE inhibitory activity, it is necessary to release a minimum quantity of hydrolysate during gastric digestion and release the maximum amount during intestinal absorption. Treatment 1 released $60.1 \%$ of protein during intestinal conditions and protein maintained an $\mathrm{IC}_{50}$ of $2.9 \mathrm{mg} / \mathrm{mL}$. Beads obtained with the blend of flamboyant carboxymethylated gum/sodium alginate could be used to control the delivery of hydrolysates with potential use as therapeutic and preventive agents.

\section{Conclusions}

A blend of Delonix regia carboxymethylated gum/sodium alginate is effective in encapsulating Phaseolus lunatus hydrolysate with ACE inhibitory activity, suggesting that it could be an effective delivery system in the preventative treatment of hypertension. Although further research is needed regarding the optimization of encapsulation, in vivo studies of delivery and the hypotensive effect of this nonconventional gum blend show that it provides an effective encapsulation system for hydrolysates with biological activity, which could be used as a nutraceutical or therapeutic agent.

\section{Acknowledgment}

This research was partially funded by the Consejo Nacional de Ciencia y Tecnología (CONACYT), Project no. CB-2008$106605 \mathrm{Z}$.

\section{References}

[1] T.-L. Chen, Y.-C. Lo, W.-T. Hu, M.-C. Wu, S.-T. Chen, and H.M. Chang, "Microencapsulation and modification of synthetic peptides of food proteins reduces the blood pressure of spontaneously hypertensive rats," Journal of Agricultural and Food Chemistry, vol. 51, no. 6, pp. 1671-1675, 2003.

[2] D. Nakano, K. Ogura, M. Miyakoshi et al., "Antihypertensive effect of angiotensin I-converting enzyme inhibitory peptides from a sesame protein hydrolysate in spontaneously hypertensive rats," Bioscience, Biotechnology and Biochemistry, vol. 70, no. 5, pp. 1118-1126, 2006.

[3] M. Daemon, D. Lombardi, F. Bosman, and S. Schwartz, "Angiotensin II induces smooth muscle cell proliferation in the normal and injured rat arterial wall," Circulation Research, vol. 68, no. 2, pp. 450-456, 1991.

[4] I. C. MacDougall, "The role of ACE inhibitors and angiotensin II receptor blockers in the response to epoetin," Nephrology Dialysis Transplantation, vol. 14, no. 8, pp. 1836-1841, 1999.

[5] E. G. Tovar-Pérez, I. Guerrero-Legarreta, A. Farrés-González, and J. Soriano-Santos, "Angiotensin I-converting enzymeinhibitory peptide fractions from albumin 1 and globulin as obtained of amaranth grain," Food Chemistry, vol. 116, no. 2, pp. 437-444, 2009.

[6] D. Betancur-Ancona, S. Gallegos-Tintoré, and L. ChelGuerrero, "Wet-fractionation of Phaseolus lunatus seeds: partial characterization of starch and protein," Journal of the Science of Food and Agriculture, vol. 84, no. 10, pp. 1193-1201, 2004.

[7] H. M. Chang, Y. C. Lee, C. C. Chen, and Y. Y. Tu, "Microencapsulation protects immunoglobulin in yolk (IgY) specific against Helicobacter pylori urease," Journal of Food Science, vol. 67, no. 1, pp. 15-20, 2002.

[8] I. T. Degim and N. Çelebi, "Controlled delivery of peptides and proteins," Current Pharmaceutical Design, vol. 13, no. 1, pp. 99117, 2007.

[9] P. V. Andreev, "Using modified starch in Russian pharmaceutical industry (a review)," Pharmaceutical Chemistry Journal, vol. 38, no. 8, pp. 447-450, 2004.

[10] D. Morochi, E. San Martin, and D. Ordoñez, "Estudio sobre la extracción y caracterización de la goma de flamboyán (Delonix 
regia)," Ciencia y Tecnología de los Alimentos, vol. 1, pp. 59-61, 1999.

[11] B. Matsuhiro, L. C. Presle, C. Saenz, and C. C. Urzua, "Structural determination and chemical modifications of the polysaccharide from seeds of Prosopis chilensis mol. (Stuntz)," Journal of the Chilean Chemical Society, vol. 51, no. 1, pp. 1-6, 2006.

[12] D. Betancur-Ancona, J. Pacheco-Aguirre, A. CastellanosRuelas, and L. Chel-Guerrero, "Microencapsulation of papain using carboxymethylated flamboyant (Delonix regia) seed gum," Innovative Food Science and Emerging Technologies, vol. 12, no. 1, pp. 67-72, 2011.

[13] V. P. Kapoor, "A galactomannan from the seeds of Delonix regia," Phytochemistry, vol. 11, no. 3, pp. 1129-1132, 1972.

[14] E. G. Azero and C. T. Andrade, "Characterisation of Prosopis juliflora seed gum and the effect of its addition to $\kappa$-carrageenan systems," Journal of the Brazilian Chemical Society, vol. 17, no. 5, pp. 844-850, 2006.

[15] A. Bahamdan and W. H. Daly, "Poly(oxyalkylene) grafts to guar gum with applications in hydraulic fracturing fluids," Polymers for Advanced Technologies, vol. 17, no. 9-10, pp. 679-681, 2006.

[16] C. Megías, M. M. Yust, J. Pedroche et al., "Purification of an ACE inhibitory peptide after hydrolysis of sunflower (Helianthus annuus L.) protein isolates," Journal of Agricultural and Food Chemistry, vol. 52, no. 7, pp. 1928-1932, 2004.

[17] P. M. Nielsen, D. Petersen, and C. Dambmann, "Improved method for determining food protein degree of hydrolysis," Journal of Food Science, vol. 66, no. 5, pp. 642-643, 2001.

[18] K. Takagi, R. Teshima, H. Okunuki, and J. Sawada, "Comparative study of in vitro digestibility of food proteins and effect of preheating on the digestion," Biological and Pharmaceutical Bulletin, vol. 26, no. 7, pp. 969-973, 2003.

[19] M. Hayakari, Y. Kondo, and H. Izumi, "A rapid and simple spectrophotometric assay of angiotensin-converting enzyme," Analytical Biochemistry, vol. 84, no. 2, pp. 361-369, 1978.

[20] D. Montgomery, Diseño y análisis de experimentos, LimusaWiley, Mexico City, México, 2004.

[21] S. Frokjaer, "Use of hydrolysates for protein supplementation," Food Technology, vol. 48, no. 10, pp. 86-88, 1994.

[22] J. Y. Je, P. J. Park, J. Y. Kwon et al., "A novel angiotensin I converting enzyme inhibitory peptide from Alaska pollack (Theragra chalcogramma) frame protein hydrolysate," Journal of Agricultural and Food Chemistry, vol. 52, no. 26, pp. 7842-7845, 2004.

[23] W. Krasaekoopt, B. Bhandari, and H. Deeth, "Evaluation of encapsulation techniques of probiotics for yoghurt," International Dairy Journal, vol. 13, no. 1, pp. 3-13, 2003.

[24] M. K. Chourasia and S. K. Jain, "Polysaccharides for colon targeted drug delivery," Drug Delivery, vol. 11, no. 2, pp. 129-148, 2004.

[25] V. Chandramouli, K. Kailasapathy, P. Peiris, and M. Jones, "An improved method of microencapsulation and its evaluation to protect Lactobacillus spp. in simulated gastric conditions," Journal of Microbiological Methods, vol. 56, no. 1, pp. 27-35, 2004.

[26] D. V. Mendanha, S. E. Molina Ortiz, C. S. Favaro-Trindade, A. Mauri, E. S. Monterrey-Quintero, and M. Thomazini, "Microencapsulation of casein hydrolysate by complex coacervation with SPI/pectin," Food Research International, vol. 42, no. 8, pp. 1099-1104, 2009. 

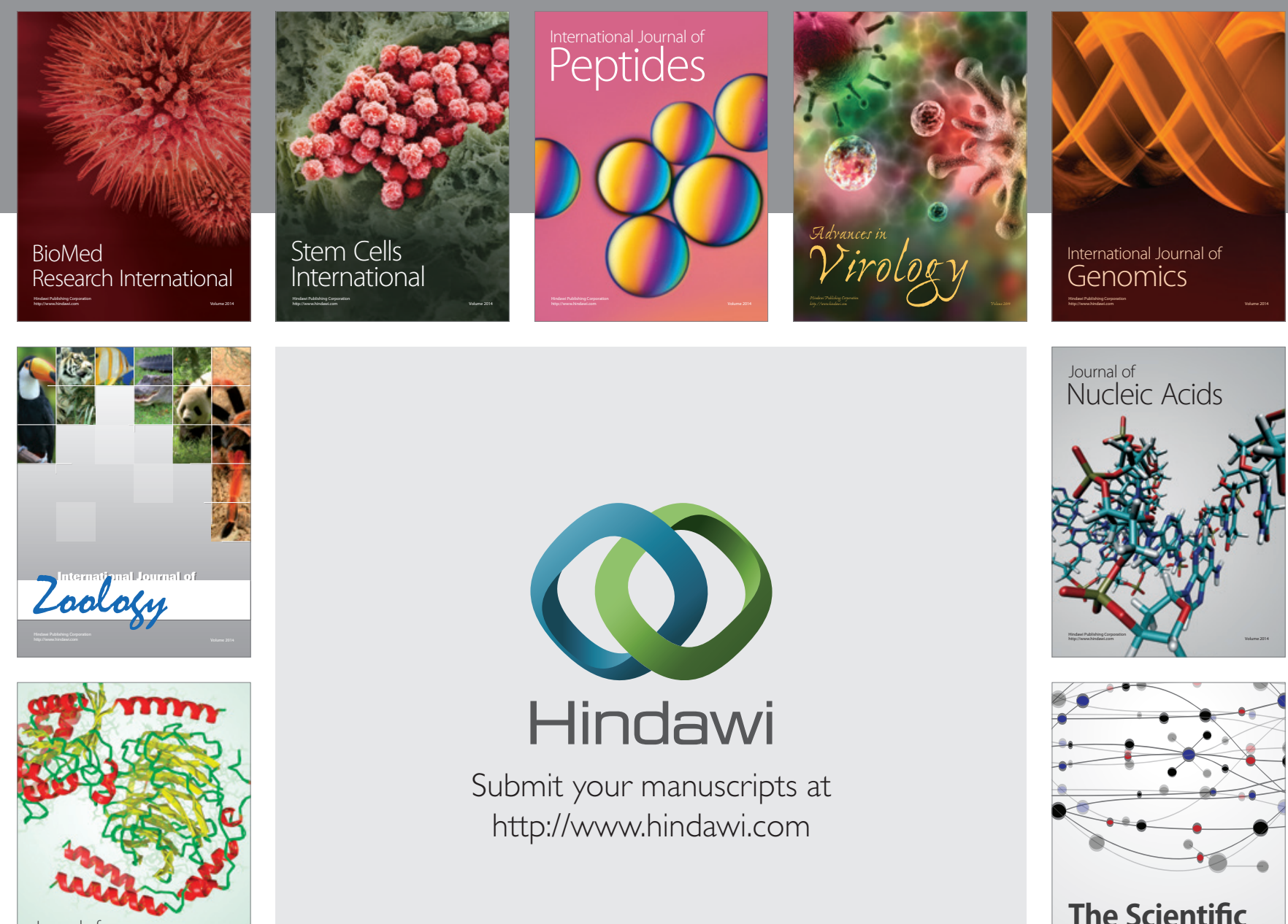

Submit your manuscripts at

http://www.hindawi.com

Journal of
Signal Transduction
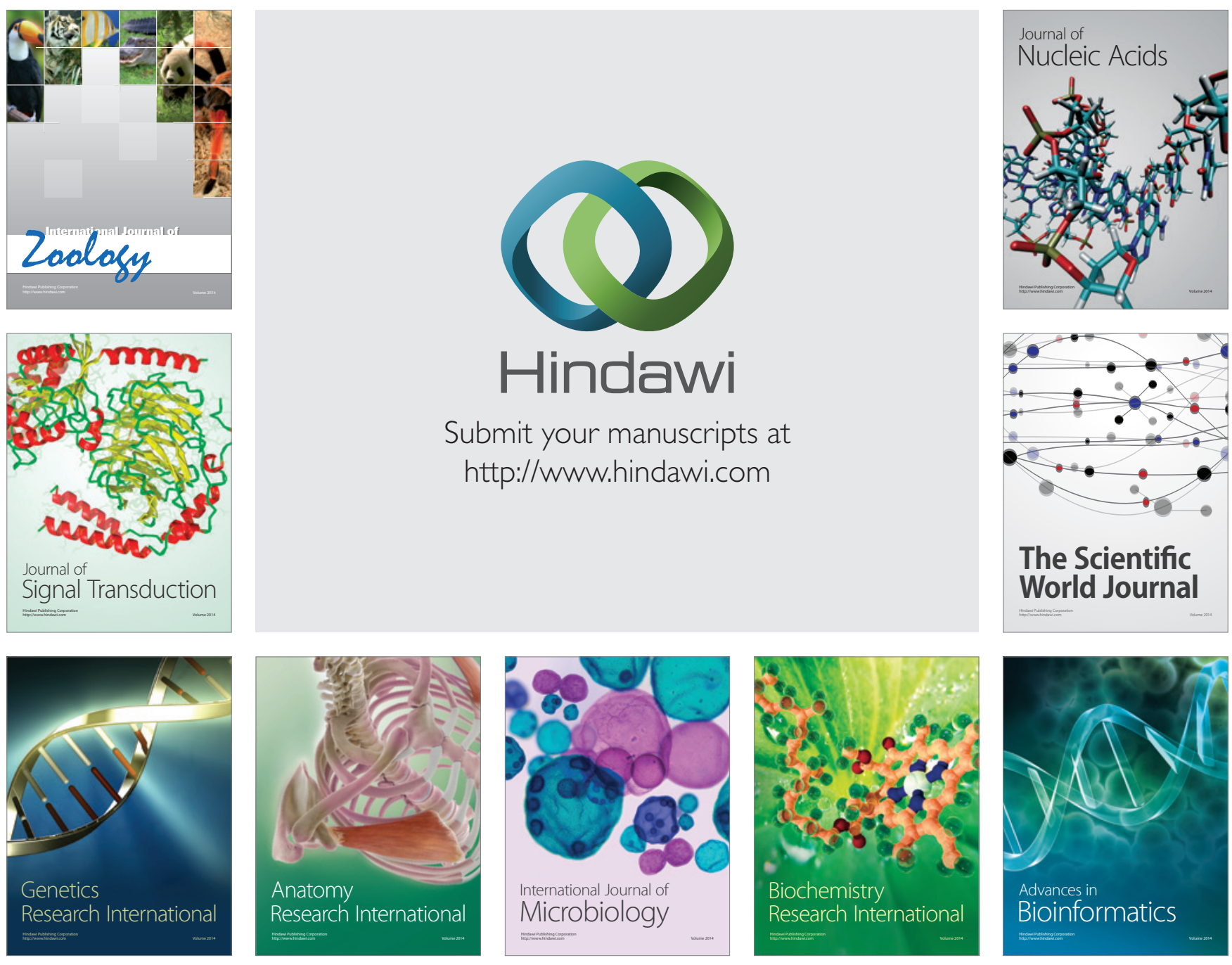

The Scientific World Journal
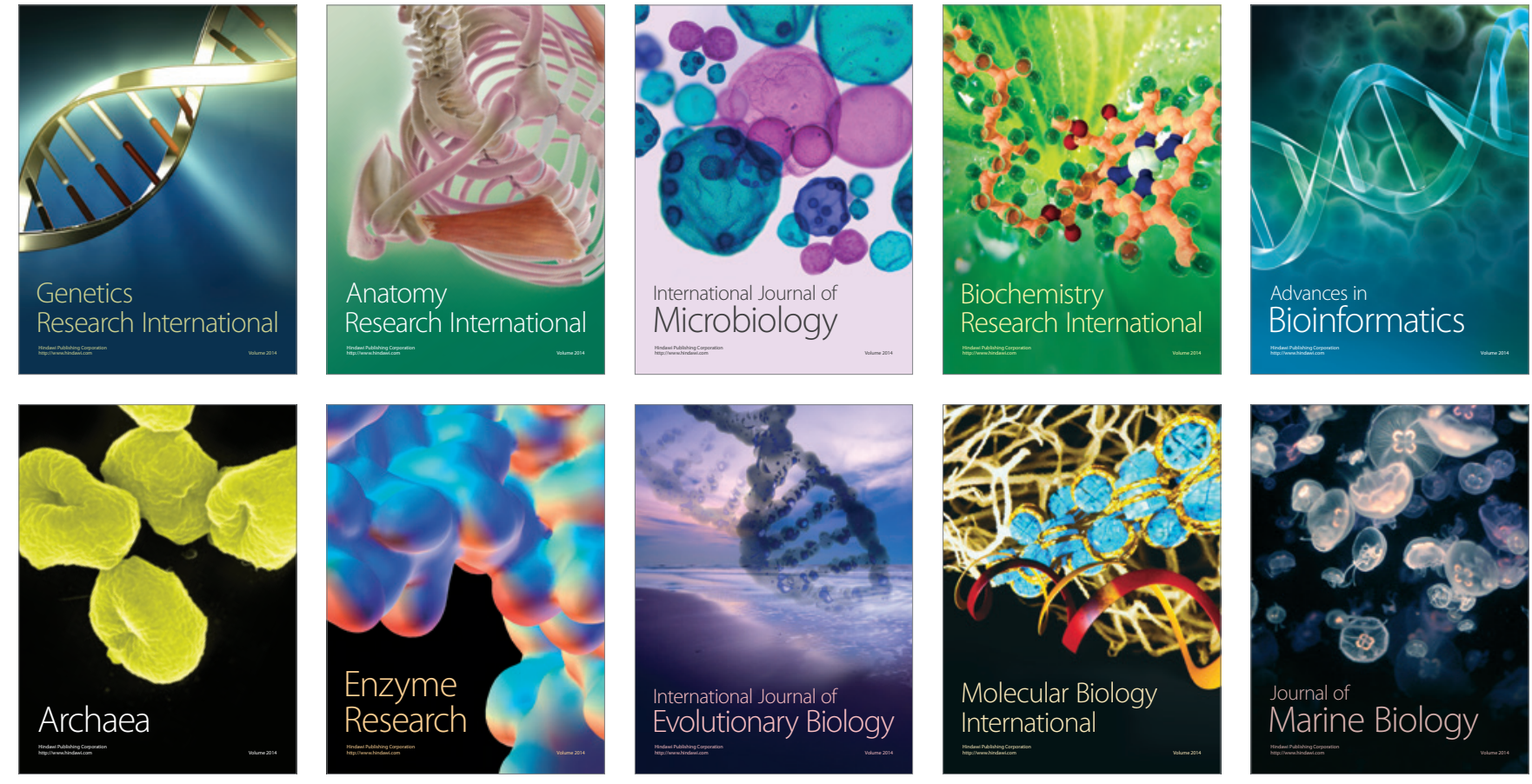